WAHANA

AKUNTANSI

Jumal Ilmiah
JURNAL ILMIAH WAHANA AKUNTANSI

Vol 15 (2) 2020, 153-162

http://journal.unj/unj/index.php/wahana-akuntansi

\title{
PENGARUH TAX AVOIDANCE, EARNINGS MANAGEMENT, DAN KEPEMILIKAN MANAJERIAL TERHADAP COST OF DEBT
}

\author{
Dan Suminar ${ }^{1},{ }^{*}$ Luh $\mathrm{Nadi}^{2}$ \\ 1,2Universitas Pamulang
}

\section{ARTICLE INFO}

Article History:

Received: 17 September 2020

Accepted: 26 November 2020

Published: 05 December 2020

Keywords:

Tax Avoidance, Earnings Management, Managerial Ownership, Cost of Debt

\begin{abstract}
This study aims to see and obtain empirical evidence regarding the effects of Tax Avoidance, Revenue Management and Managerial Ownership Against Debt Costs. This research was conducted at the manufacturing sector company consumer goods listed on the Indonesia Stock Exchange in 2014-2018. Population in this study were 51 companies listed on the Stock Exchange Indonesia se;ected using purposive sampling method, namely technique taking data sources with certain considerations. Data analysis method this research uses multiple linear regression analysis. Based on the research results show that Tax Avoidance has no effect on the Cost of Debt, Earning Management affects the Cost of Debt, and Managerial Ownership has no effect on the cost of accounts payable.
\end{abstract}

How to Cite:

Suminar, Dan, Luh Nadi. Pengaruh Tax Avoidance, Earnimgs Management, dan Kepemilikan Manajerial Terhadap Cost of Debt. Jurnal Ilmiah Wahana Akuntansi, 15(2), 153-162. https://doi.org/10.21009/wahana.15.023 
PENDAHULUAN

Biaya utang merupakan tingkat pengembalian yang diinginkan kreditur saat memberikan pendanaan kepada perusahaan. Tingkat pengembalian yang diberikan perusahaan inilah yang akan menjadi biaya utang atau cost of debt bagi perusahaan (Marcelliana, 2014). Cost of Debt diukur dengan membagi beban bunga yang dibayarkan oleh perusahaan dalam periode satu tahun dibagi dengan jumlah rata-rata pinjaman jangka panjang dan pendek yang berbunga selama tahun tersebut (Masri dan Martani, 2012). Pengelolaan perusahaan yang efektif dan efisien biasanya dikaitkan dengan perolehan laba yang optimal. Untuk memperolehnya, perusahaan harus dapat meningkatkan pendapatan dan menekan beban pada tingkat minimum. Salah satu beban yang dikelola oleh perusahaan adalah beban pajak.

Menurut Sari (2014) menjelaskan bahwa secara hukum tax avoidance tidak dilarang, namun sering mendapat sorotan yang kurang baik dari kantor pajak karena dianggap memiliki konotasi negatif dan menunjukkan perilaku ketidakpatuhan. Konotasi negatif ini akan membuat kreditor memandang praktik tax avoidance yang dilakukan perusahaan sebagai tindakan yang mengandung risiko. Upaya manajer untuk memilih metode akuntansi tertentu yang dapat menghasilkan informasi laba yang diinginkan disebut sebagai manajemen laba (earnings management). Tujuan perusahaan melakukan earnings management yaitu untuk menaikan dan menurunkan pelaporan laba sesuai dengan yang diharapkan.
Manajemen laba atau earnings management merupakan intervensi manajemen dengan sengaja dalam proses penentuan laba, biasanya untuk memenuhi tujuan pribadi (Subramanyam \& Wild, 2014). Kepemilikan Manajerial adalah jumlah kepemilikan saham oleh pihak manajemen dari seluruh modal saham perusahaan yang dikelola (Agnes, 2013:4). Kepemilikan Manajerial dapat mengurangi konflik keagenan karena apabila pihak manajemen mempunyai bagian dari perusahaan maka manajemen akan maksimal dalam menjalankan aktivitas perusahaan dan mengurangi kecurangan yang terjadi didalam manajemen, dapat secara efektif meningkatkan kinerja manajer. Kualitas informasi yang dilaporkan dapat dipengaruhi oleh kepemilikan saham manajerial. Tekanan dari pasar modal menyebabkan perusahaan dengan kepemilikan saham manajerial yang rendah akan memilih metode yang dilaporkan, yang sebenernya tidak mencerminkan keadaan ekonomi dari perusahaan yang bersangkutan.

Berdasarkan latar belakang di atas, maka peneliti tertarik untuk melakukan penelitian yang bertujuan untuuk mengetahui apakah Tax Avoidance, Earnings Management, dan Kepemilikan Manajerial memiliki pengaruh terhadap Cost Of Debt.

\section{TINJAUAN TEORI}

Teori agen dengan penelitian yaitu adanya hubungan antara investor dan manajemen pengelola perusahaan yang mengharuskan perusahaan mampu membayar 
hutangnya dikemudian hari, sehingga peneliti menggunakan teori tersebut. Teori stakeholder dengan penelitian ini yaitu adanya hubungan stakeholder atau investor dan manajemen dalam rangka mencapai kepentingan perusahaan yang seharusnya tidak dibatasi dengan asumsi konvensional yaitu mencari keuntungan saja. Sehingga penulis menggunakan teori tersebut. Cost of Debt adalah tingkat pengembalian bunga yang harus dibayarkan perusahaan kepada kreditur atas pinjaman yang telah dilakukan.

Tax Avoidance adalah upaya memperkecil besarnya tingkat pembayaran pajak yang harus dilakukan perusahaan yang sesuai dengan UU PPh pasal 18 ayat 1 dan PMK No. 169/PMK.03/2015 tentang penentuan besarnya perbandingan antara utang dan modal perusahaan untuk keperluan perhitungan pajak penghasilan. Manajemen Laba adalah upaya Manajer dalam menaikkan dan menurunkan laba sesuai yang diinginkan manajemen untuk mendapatkan keuntungan dengan cara merekayasa laporan keuangan untuk mengelabui pemakai informasi laporan keuangan. Kepemilikan manajerial adalah merupakan keadaan dimana seorang manajer disuatu perusahaan merangkap juga sebagai pemegang saham didalam perusahaan tersebut.

\section{METODE PENELITIAN}

Jenis penelitian yang digunakan dalam penelitian ini adalah penelitian kuantitatif deskriptif untuk mengetahui faktor-faktor apa saja yang dapat mempengaruhi cost of debt pada perusahaan manufaktur sektor barang konsumsi yang terdaftar di Bursa Efek Indonesia (BEI).
Penelitian ini dilakukan pada perusahaan manufaktur sektor barang konsumsi yang terdaftar di Bursa Efek Indonesia (BEI) pada periode 5 tahun mulai tahun 2014-2018. Pemilihan lokasi penelitian di Bursa Efek Indonesia (BEI) melalui situs resmi www.idx.co.id didasarkan atas pertimbangan objektif sesuai dengan tujuan penelitian.

Variabel dependen atau variabel pada penelitian ini adalah biaya utang (cost of debt) dan variabel independen yang digunakan dalam penelitian ini adalah Tax Avoidance, Earnings Management dan Kepemilikan Manajerial. Populasi dalam penelitian ini sebanyak 51 perusahaan yang terdaftar di BEI pada sektor barang konsumsi. Sampel yang digunakan dalam penelitian ini sebanyak 13 perusahaan manufaktur sektor barang konsumsi yang terdaftar di BEI. Data yang dikumpulkan dalam penelitian ini berupa data jenis kuantitatif sekunder yang diperoleh dari idx situs resmi Bursa Efek Indonesia.

Teknik analisis data pada penelitian ini memakai uji statistik deskriptif dan analisa regresi data panel yang dapat dibagi menjadi 3 yaitu: (1) Pooled Least Square atau Common Effect Model, dimana metode ini umumnya menggunakan Ordinary Least Square atau teknik kuadrat kecil untuk mengestimasi model data panel; (2) Random Effect Model, dimana model ini dikenal dengan sebutan model Generalized Least Square (GLS). Apabila probabilitas signifikan F statistk $<$ alpha $=0,05$ maka model fixed effect, namun jika nilai probabilitas signifikan $\mathrm{F}$ statistik $>$ alpha $=0,05$ 
maka model yang lebih baik adalah model common effect; dan (3) Fixed Effect Model, di mana model dengan intercept berbeda-beda untuk subjek (cross-section). Model ini disebut dengan model Least Square Dummy Variables (LSDV).

Pengujian model dalam penelitian ini menggunakan uji chow, uji hausman, dan uji Lagrange Multiplier. Dan uji asumsi klasik yang akan digunakan adalah uji normalitas, multikolinearitas, heterokedastisitas, dan autokorelasi.

Menurut Ghozali (2013) analisis uji regresi linear berganda penting digunakan untuk meramalkan bagaimana keadaan variabel independen sebagai prediktor dan untuk mengetahui arah hubungan antara variabel independen dengan variabel dependen, apakah masing-masing variabel independen berhubungan positif atau negatif. Sedangkan untuk uji hipotesis yang digunakan dalam penelitian ini adalah uji F (simultan), Uji T (parsial) dan Uji Koefisien Determinasi.

\section{HASIL DAN PEMBAHASAN}

\section{Uji Statistik Deskriptif}

Berdasarkan tabel nilai observasi sebesar 65 yang menunjukkan bahwa sampel data yaitu sebanyak 65 data setiap variabel, yang terdiri dari cost of debt, tax avoidance, earnings management dan kepemilikan manajerial, selama 5 tahun penelitian yaitu periode 2014-2018. Dari hasil uji statistik dapat diketahui bahwa $X_{1}$ yaitu Tax Avoidance mempunyai nilai minimum sebesar 0,11 yaitu pada perusahaan Langgeng Makmur Industry Tbk tahun 2017, nilai maksimum sebesar 2,27 satuan pada perusahaan Indofood Sukses Makmur Tbk tahun 2017, nilai mean (rata-rata) sebesar 0,39 satuan dan standar deviasi sebesar 0,33.

Variabel yang kedua atau $X_{2}$ yaitu Earnings management mempunyai nilai minimum sebesar $-0,18$ yaitu pada perusahaan Martina Berto Tbk tahun 2018, nilai maksimum sebesar 0,33 pada perusahaan Kimia Farma (Persero) Tbk tahun 2015, nilai mean (rata-rata) sebesar -0,002 dan standar deviasi sebesar 0,067 .

Variabel yang ketiga Kepemilikan Manajerial atau $\mathrm{X}_{3}$ mempunyai nilai minimum sebesar adalah 0,000 yaitu pada perusahaan Kimia Farma (Persero) tahun 2015, nilai maksimum sebesar 138,0340 pada perusahaan Ultrajaya Milk Industry \& Trading Co Tbk tahun 2018, nilai mean (rata-rata) sebesar 13,2961 dan standar deviasi 28,7315.

Variabel Y yaitu Cost of Debt memperoleh nilai minimum sebesar 0,0003 yaitu pada perusahaan Kimia Farma (Persero) Tbk tahun 2014, nilai maksimum sebesar 0,0779 pada perusahaan Langgeng Makmur Industri Tbk tahun 2015, nilai mean (rata-rata) sebesar 0,0317 dan standar deviasi 0,0202.

\section{Hasil Uji Data Panel}

1. Uji Chow

Hasil Uji Chow dari penelitian ini disajikan pada Tabel 1.

Dari Tabel 1 dapat dilihat bahwa nilai probabilitas cross-section $\mathrm{F}$ adalah 0,0000 dan nilai probabilitas crosssection chi-square 0,0000 keduanya 
memiliki nilai $<0,05$, maka dapat disimpulkan bahwa model yang lebih baik adalah model fixed effect dari pada model common effect.

Tabel 1

Hasil Uji Chow

\begin{tabular}{|c|c|c|c|}
\hline Eflects Test & Statsstc & dt. & Prob. \\
\hline Closs-section F & 10.626415 & $(12,49)$ & 0.0000 \\
\hline Cross section Chisquare & 83.003790 & 12 & 0.0000 \\
\hline
\end{tabular}

Sumber: Data diolah oleh peneliti, Tahun 2020

\section{Uji Hausman}

Hasil pengujian Hausman menunjukan nilai statistik zchi square (probabilitas) adalah 0,3872 atau >0,05. Maka model penelitian random effect lebih tepat digunakan dibanding dengan model fixed effect .

3. Uji Lagrange Multiplier (Uji LM)

Hasil pengujian LM menunjukkan nilai Breusch-Pagan cross-section adalah 0,0000 atau $<0,05$. Maka model penelitian random effect lebih tepat digunakan dibanding dengan model fixed effect.

\section{Hasil Uji Asumsi Klasik}

1. Uji Normalitas

Hasil uji normalitas dapat dilihat bahwa nilai Jarque-Bera yang diperoleh adalah sebesar 2,282569 dengan probabilitas 0.319408 atau $>0,05$ yang berarti nilai residual berdistribusi normal. Selain menggunakan histogram, uji normalitas dapat diketahui dengan menggunakan uji Jurque-Bera, yaitu dengan membandingkan Jurque-Bera dengan nilai Chi Square tabel. Berdasarkan tabel dapat diketahui bahwa nilai Jurque-Bera adalah 2,282569 dan nilai Chi Square tabel dengan 2 df dan 0,05 untuk nilai signifikasi adalah 5,99, yang menunjukan bahwa nilai JurqueBera < Chi Square $(2,282569<5,99)$. Sehingga dapat disimpulkanbahwa data berdistribusi normal.

2. Uji Multikolinearitas

Hasil uji multkolinieritas dapat dilihat nilai korelasi antara tax avoidance dan earnings management dalam penelitian ini sebesar 0,023717. Korelasi antara tax avoidance dan kepemilikan manajerial sebesar -0,175047 dan korelasi antara earnings management dan kepemilikan manajerial sebesar -0,087619. Yang berarti masih di bawah 0.90 dan data dalam penelitian ini terbebas dari masalah multikolinieritas antar variabel.

3. Uji Heterokedastisitas

Berdasarkan hasil uji heterokedastisitas menunjukan bahwa nilai probabilitas chi square(3) adalah 0,4568 atau $>0,05$. Dari hasil ini dapat disimpulkan bahwa uji glejser tidak mengindikasikan adanya gejala heterokedastisitas.

4. Uji Autokorelasi

Dari hasil uji autokorelasi menunjukkan nilai Durbin-Watson sebesar 1,932590. Data tidak mengalami autokorelasi apabila $\mathrm{du}<\mathrm{dw}<4$-du. Cara melihat 
nilai du dari tabel Durbin-Watson yaitu simbol ' $\mathrm{k}$ ' menunjukan banyaknya variabel independen dalam penelitian dan ' $\mathrm{n}$ ' menunjukan banyaknya observasi dalam penelitian. Penelitian ini menggunakan 3 variabel independen dan data penelitian sebanyak 65, maka nilai du sebesar 1.6960 dan 4- du adalah $2.304(\mathrm{du}<\mathrm{dw}<4-\mathrm{du})$ atau $1.6960<1.932590<2.304$. Sesuai hasil tersebut dapat disimpulkan bahwa tidak terjadi autokorelasi.

\section{Analisis Regresi Liniear Berganda}

Dari persamaan hasil uji analisis regresi liniear berganda dapat dilihat hubungan antara variabel independen yaitu Tax Avoidance, Earnings Management, dan Kepemilikan Manajerial terhadap Cost Of Debt adalah: (1) Nilai koefisien regresi pada variabel Tax Avoidance sebesar 2,18 . Hal tersebut menunjukan bahwa jika variabel Tax Avoidance mengalami kenaikan 1\%, maka variabel Cost of Debt akan meningkat sebesar 2,18\%, dengan asumsi variabel lainnya (Earnings Management, Kepemilikan Manajerial) dianggap tetap (konstan); (2) Nilai koefisien variabel Earnings Management sebesar $0,13 \%$. Hal ini menunjukkan bahwa jika variabel Earnings Management mengalami kenaikan sebesar 1\%, maka variabel Cost Of Debt akan meningkat sebesar $0,13 \%$, dengan asumsi variabel lainnya (Tax Avoidance, Kepemilikan Manajerial) dianggap tetap (konstan); (3) Nilai koefisien regresi pada variabel Kepemilikan Manajerial sebesar -5,24\%. Hal ini menunjukan bahwa jika variabel Kepemilikan Manajerial mengalami kenaikan 1\%, maka variabel Cost Of
Debt akan menurun sebesar - 5.24E-06, dengan asumsi variabel lainnya (Tax Avoidance, Earnings Management) dianggap tetap (konstan).

\section{Uji Hipotesis}

1. Uji F (Simultan)

Hasil uji $\mathrm{F}$ menunjukan bahwa nilai $\mathrm{F}$ hitung sebesar 9,439976 sementara F tabel dengan tingkat signifikansi 0,05. Untuk mencari $F$ tabel dengan jumlah sampel $(n)=65$, jumlah variabel $(k)=4$, dan taraf signifikan sebesar 0,05 , sehingga df $1=\mathrm{k}-1=4-1=3$ dan df $2=\mathrm{n}$ $\mathrm{k}=65-4=61$ maka diperoleh $\mathrm{F}$ tabel sebesar 2,76, sehingga $F$ hitung 9,439976 $>\mathrm{F}$ tabel 2,76 dengan tingkat signifikan pada tabel sebesar $0,000033<0.05$. Hal ini menunjukan bahwa Tax Avoidance, Earnings Management, dan Kepemilikan Manajerial secara simultan berpengaruh positif dan signifikan terhadap Cost of Debt.

2. Uji T (Parsial)

Berdasarkan hasil uji $\mathrm{T}$ dapat diketahui bahwa nilai $\mathrm{T}$ hitung Tax Avoidance adalah sebesar 0,004338. Jika dibandingkan dengan $\mathrm{T}$ tabel pada tingkat signifikan $0,05 \mathrm{df}=(\mathrm{n}-\mathrm{k}-1)=(65-3-1)=$ 61 yaitu sebesar 1,67022, maka T hitung $0,004338<\mathrm{T}$ tabel 1,67022. Nilai probabilitas signifikansi sebesar 0,9966 juga menunjukan lebih besar pada tingkat signifikansi yang telah ditentukan yaitu $0,05(0,9966>0,05)$. Hal ini menunjukkan bahwa Tax Avoidance 
secara parsial tidak berpengaruh terhadap Cost Of Debt.

Nilai $\mathrm{T}$ hitung Earnings Management adalah sebesar 5,309801 jika dibandingkan dengan $\mathrm{T}$ tabel pada tingkat signifikan $0,05 \mathrm{df}=(\mathrm{n}-\mathrm{k}-1)=(65-3-1)=61$ yaitu sebesar 1,67022, maka $\mathrm{T}$ hitung $5,309801>\mathrm{T}$ tabel 1,67022. Nilai probabilitas signifikan sebesar 0,0000 juga menunjukan nilai yang lebih kecil dari nilai pada tingkat signifikansi yang telah ditentukan yaitu $0,05(0.0000<0.05)$. Hal ini menunjukan bahwa Earnings Management secara parsial berpengaruh terhadap Cost Of Debt.

Nilai $\mathrm{T}$ hitung Kepemilikan Manajerial adalah sebesar -0,072372 jika dibandingkan $\mathrm{T}$ tabel pada tingkat signifikan $0,05 \mathrm{df}=(\mathrm{n}-\mathrm{k}-1)=(65-3-1)=$ 61 yaitu sebesar 1,67022, maka T hitung $0,072372<\mathrm{T}$ tabel 1,67022. Nilai probabilitas signifikan sebesar 0,9425 juga menunjukan nilai yang lebih besar dari nilai pada tingkat signifikansi yang telah ditentukan yaitu $0.05(0.9425>0.05)$. Hal ini menunjukan bahwa Kepemilikan Manajerial secara parsial tidak berpengaruh terhadap Cost Of Debt.

\section{Koefisien Determinasi}

Berdasarkan hasil uji determinasi diketahui nilai koefisien determinasi (Adjusted $R$ Square) adalah 0,283475. Hal ini berarti seluruh variabel bebas Tax Avoidance, Earnings Management, dan Kepemilikan Manajerial mampu menjelaskan variabel dependen Cost of Debt sebesar 28,34\%.
Sedangkan sisanya $71,66 \%$ dapat dipengaruhi oleh variabel lain yang tidak ada dalam penelitian ini.

\section{Pengaruh Tax Avoidance Terhadap Cost of Debt}

Tax Avoidance secara parsial tidak berpengaruh terhadap Cost Of Debt. Hasil penelitian ini sesuai dengan penelitian Wardani, dkk (2018) yang menyatakan Tax Avoidance tidak berpengaruh terhadap Cost Of Debt. Hal ini dikarenakan Cost Of Debt pada sampel penelitian ini relatif rendah sehingga menurunkan resiko kegagalan bayar hutang perusahaan yang dampaknya terhadap penghindaran pajak tidak begitu besar.

\section{Pengaruh Earninsg Management Terhadap Cost of Debt}

Earnings Management secara parsial berpengaruh terhadap Cost Of Debt. Hasil penelitian ini sesuai dengan penelitian Purnamasari (2018) yang menyatakan Earnings Management berpengaruh terhadap Cost Of Debt. Hal ini karena Earnings Management atau manajemen untuk mempengaruhi persepsi investor, terutama untuk mempengaruhi kaputusan membeli saham perusahaan.

\section{Pengaruh Kepemilikan Manajerial Terhadap Cost of Debt}

Kepemilikan Manajerial secara parsial tidak berpengaruh terhadap Cost Of Debt. Hasil ini sesuai dengan penelitian Erniawati, dkk (2019) yang menyatakan bahwa kepemilikan 
manajerial tidak berpengaruh terhadap Cost $O f$ Debt. Hal ini dikarenakan manajer tidak akan melakukan hal yang memberikan banyak manfaat bagi perusahaan, namun manajer akan melakukan hal demi ini demi kepentingannya sendiri dengan menggunakan sumber daya perusahaan.

\section{KESIMPULAN DAN SARAN}

Hasil penelitian ini menunjukkan bahwa Tax Avoidance dan Kepemilikan Manajerial tidak berpengaruh terhadap Cost of Debt. Sedangkan Earnings Management berpengaruh terhadap Cost of Debt.

Hasil penelitian ini menunjukkan kemampuan ketiga variabel independen yang diteliti hanya sebesar 28,34\%. Sehingga masih terdapat variabel-variabel lain yang diduga dapat mempengaruhi Cost of Debt perusahaan. Penelitian selanjutnya diharapkan dapat menguji variabel lainnya tersebut.

\section{DAFTAR PUSTAKA}

Agnes. (2013). Pengaruh Kepemilikan Manajerial Struktur Modal dan Ukuran Perusahaan terhadap Nilai Perusahaan. Universitas Negeri Padang.

Akhmad Riduwan, Enggar Febria Vernanda Sari. (2013). Pengaruh Corporate Governance, Kepemilikan Institusional, Kepemilikan Manajerial dan Komite Audit terhadap Nilai Perusahaan (Vol. 1, No. 1). Sekolah Tinggi Ilmu Ekonomi Indonesia (STIESIA) Surabaya.

Ashkhabi Reza Ibnu, Linda Agustina. (2015). Pengaruh Corporate Governance Index, Struktur Kepemilikan Perusahaan Dan Ukuran Perusahaan Terhadap Biaya Utang (Studi Empiris Pada Perusahaan Peserta Corporate Governance
Perception Index Tahun 2011-2013) (Vol. 4, No. 3). Jurnal Analisis Accounting Universitas Negeri Semarang.

Arfan. (2013). Akuntansi Keperilakuan Edisi 2. Jakarta : Salemba Empat.

Baltagi, B., H. (2005). Econometrics Analysis of Panel Data. Chicester England: Jhon Wiley \& Sons Ltd.

Basuki, Agus. Tri, dan Prawoto, Nano. (2016). Analisis Regresi Dalam Penelitian Ekonomi dan Bisnis: Dilengkapi Aplikasi SPSS \& Eviews. Jakarta : Rajawali Pers.

Bursa Efek Indonesia: www.idx.co.id

Butar Butar, S. (2007). Modul Statistik dan Aplikasi SPSS. Fakultas Ekonomi UNIKA Soegijapranata.

Erniawati, Ika. (2014). Analisis Pengaruh Tax Avoidance terhadap Biaya Utang dan Kepemilikan Institusional. Published Skripsi. Universitas Muhamadiyah Surakarta.

Ghozali, I. (2006). Aplikasi Analisis Multivariate dengan Program SPSS. Semarang: Cetakan IV, Badan Penerbit Universitas Diponegoro.

Ghozali, Imam. (2013). aplikasi analisis multivariate dengan program spss. Edisi ketujuh. Semarang: Badan Penerbit Universitas Diponegoro.

Hadiwijaya, R.C., \& Rohman, A. (2013). Pengaruh Intelektual Capital Terhadap Nilai Perusahaan Dengan Kinerja Keuangan Sebagai Variabel Intervening.

Hoque, et al. 2011. Tax Avoidance Crimes- A Study on Some Corporate Firms of Bangladesh.

Jensen, M. C. \& Meckling, W. H. (1976). Theory of the Firm: Managerial Behaviour, Agency Costand 
Ownership Structure. Journal of Financial Economics, 3(4), 305-360. Kuncoro, M. Metode Riset Untuk Bisnis \& Ekonomi. Jakarta: PT Gelora Aksara Pratama.

Marcelliana, Elsa. (2014). Pengaruh Tax Avoidance terhadap Cost of Debt pada Perusahaan Manufaktur yang Terdaftar di Bursa Efek Indonesia Periode 2010-2012. Skripsi. Universitas Atma Jaya Yogyakarta.

Marsi, Indah dan Dwi Martani. (2010). Pengaruh Tax Avoidance terhadap Cost Of Debt. Jurnal Fakultas Ekonomi Universitas Indonesia.

Masri, Indah dan Dwi Martani. (2012). Pengaruh Tax Avoidance terhadap Cost of Debt. Simposium Nasional Akuntansi $X V$. Universitas Indonesia, Depok.

Pernamasari, Rieke. (2018). Penerapan Good Corporate Governance dan Earning Management terhadap Biaya Hutang pada Perusahaan BUMN Listing CGPI 2010 2012. Universitas Mercu Buana.

PSAK ED 26 (Revisi 2011). Pernyataan Standar Akuntansi Keuangan, Biaya Pinjaman.

Rahmawati. (2015). Pengaruh Penghindaran Pajak dan Good Corporate Governance terhadap Biaya Utang (Studi Empiris pada Perusahan Manufaktur yang Terdaftar di BEI Tahun 2009- 2013). Skripsi Fakultas Ekonomi Universitas Negeri Padang.

Safiq, Muhamad, Yustina Ina Andi, Muhaqiyah Aeniyatul. (2018). Dampak Earnings Management dalam Hubungan Kinerja dengan Cost of Debt (Studi Pada Perusahaan Manufaktur di Bursa Efek Indonesia). Jurnal STIE Indonesia.

Santosa, Ekasanti, Janice, Kurniawan Heni. (2016). Analisis pengaruh tax avoidance terhadap cost of debt pada perusahaan manufaktur yang terdaftar di bei selama periode 2010-2014. Jurnal Universitas Atma Jaya Yogyakarta.

Saputro, Edi, Rendi. (2018). Pengaruh Tax Avoidance Terhadap Biaya Utang (Cost Of Debt) Dengan Transfaransi Perusahaan
Sebagai Variabel Moderating (Studi Empiris Pada Perusahaan Manufaktur Yang Terdaftar Di BEI Periode 20132017).

Suandy, Erly. (2011). Hukum Pajak (Edisi 5). Jakarta: Salemba Empat.

Suandy Erly. (2014). Hukum Pajak, Edisi 6. Yogyakarta : Penerbit Salemba Empat.

Suandy, Elly. 2016. Perencanaan Pajak. Edisi 6. Jakarta: Salemba Empat.

Subramanyam, K. R. \& Wild, J. J. (2014). Analisis Laporan Keuangan (Dewi Yanti, Penerjemah.). Jakarta: Salemba Empat.

Sulistyanto, H. Sri, (2008). Manajemen Laba Teori dan Model Empiris. Jakarta: Grasindo.

Sugiyono. (2005). Memahami Penelitian Kualitatif. Bandung: Alfabeta.

Sugiyono. (2009). Metode Penelitian Kuantitatif Kualitatif dan R\&D. Bandung: Alfabeta.

Sugiyono. (2011). Metode Penelitian Kuantitatif Kualitatif dan $R \& D$. Penerbit Alfabeta, Bandung.

Sugiyono. (2013). Metode Penelitian Kuantitatif, Kualitatif dan R\&D. Bandung: Alfabeta.

Sujarweni, V. (2015). Metodologi Penelitian Bisnis dan Ekonomi. Yogyakarta: Pustaka Baru Press.

Swissia Pebrina, Et Al. (2018). Pengaruh Struktur Kepemilikan Institusional, Kepemilikan Manajerial, Kepemilikan Keluarga, Pengungkapan Sukarela Dan Leverage Terhadap Biaya Utang. Jurnal akuntansi dan keuangan Fakultas Ekonomi IIB Darmajaya, Lampung.

UUD No 28 Tahun 2008. Ketentuan Umum dan Tata Cara Perpajakan (KUP)

Wardani Kusuma Dewi, Rumahorbo Sari D H. (2018). Pengaruh Penghindaran Pajak, Tata Kelola dan Karakteristik Perusahaan 
Terhadap Biaya Hutang. Jurnal Universitas Sarjanawiyata Tamansiswa Yogyakarta.

Warsono. (2003). Manajemen Keuangan Perusahaan. Jilid 1. Bayu Media Publishing. Malang.

Wibowo, Paulina Febriani dan Yeterina Widi Nugrahanti. (2013). Corporate Governance Mechanisms to Cost of Debt. Jurnal Universitas Kristen Satya Wacana Salatiga.

Wicaksono, Anas Budi. 2013. Pengaruh Kecakapan Manajerial Terhadap Praktik Manajemen Laba Dengan Corporate Governance Sebagai Variabel Pemoderasi (Studi Pada Perusahaan Yang Terdaftar Tahun 2009-2011 Di BEI). Skripsi. Semarang: Universitas Diponegoro.

Widarjo, Wahyu. (2010). Pengaruh Ownership Retention, Investasi Dari Proceeds, Dan Reputasi Auditor Terhadap Nilai Perusahaan Dengan Kepemilikan Manajerial Dan Institusional Sebagai Variabel Pemoderasi. Simposium Nasional Akuntansi XIII.

Winarno, Wing Wahyu. (2009). Analisis Ekonometrika dan Statistika dengan Eviews. Edisi kedua. UPP STIM YKPN. Yogyakarta.

Zahro, Fatimatuz, et al (2018) Pengaruh penghindaran pajak dan good corporate governance terhadap cost of debt. Program Studi Akuntansi, Fakultas Ekonomi, Universitas Negeri Islam Malang. 